\title{
In Vitro and in Vivo Antidiabetic Activity of Rumex Vesicarius Leaves Extract in Streptozotocin Induced Diabetic Albino Wister Rats
}

\author{
Reddy NS*, Ramanjaneyulu K, Sabbani V and Choday V
}

Department of Pharmacology, Vishnu Institute of Pharmaceutical Education and Research, Vishnupur, Narsapur, Medak, Telangana, India

*Corresponding author: Reddy NS, Department of Pharmacology, Vishnu Institute of Pharmaceutical Education and Research, Vishnupur, Narsapur, Medak, Telangana, India, Tel: +919491229728; E-mail: satishreddy949@gmail.com

Received date: April 03, 2017; Accepted date: June 06, 2017; Published date: June 12, 2017

Copyright: ( 2017 Reddy NS, et al. This is an open-access article distributed under the terms of the Creative Commons Attribution License, which permits unrestricted use, distribution, and reproduction in any medium, provided the original author and source are credited.

\begin{abstract}
Objective: The principle goal of this work is to assess the in vitro and in vivo antidiabetic activity of ethanolic extract of Rumex vesicarius in the streptozotocin actuated diabetic rats.

Methods: Single intraperitoneal injection (i.p.) of streptozotocin (60 mg/kg body weight) was used for induction of diabetes in albino rats. The induction of diabetes was confirmed after 3 days of streptozotocin injection and rats with fasting blood glucose levels were greater than $200 \mathrm{mg} / \mathrm{dl}$ and were considered to be diabetic used in the experiment. Rumex vesicarius at a once daily dose of $100 \mathrm{mg} / \mathrm{kg}, 200 \mathrm{mg} / \mathrm{kg}$ and $400 \mathrm{mg} / \mathrm{kg}$ along with Glibenclamide $10 \mathrm{mg} / \mathrm{kg}$ was also given for 1 week. On the last day, the blood was collected from all groups of rats which have fasted overnight by puncturing the retro-orbit of the eye under mild ether anesthetic condition.
\end{abstract}

Results: The statistical data indicated that the different doses of Rumex vesicarius significantly decrease the level of blood glucose in streptozotocin induced rats. This result indicated that Rumex vesicarius can protect pancreatic $\beta$-cells from streptozotocin induced damage which is confirmed by the results of histopathological examination of pancreas.

Conclusion: Our investigation has clearly indicated that ethanolic extract of Rumex vesicarius showed antihyperglycemic activity due to its possible systemic effect involving in pancreatic mechanism.

Keywords: Rumex vesicarius, Alpha glucosidase; Glibenclamide; Diabetes; Histopathology; Pancreas; Albino Rats

\section{Introduction}

Rumex vesicarius Linn. (Polygonaceae) is commonly called as Chukka kura in Telugu, Chukra in Hindi, Bladder Dock in English [1]. Rumex vesicarius $L$. is a wild edible plant used as a sorrel and collected in spring season and eaten fresh or cooked. Rumex vesicarius $L$. has many important medicinal uses such as treatment of hepatic diseases, bad digestion, diurectic, laxative, tonic, analgesic, purgative and antibacterial agents. The plant can be used to reduce biliary disorders and control cholestrol levels [2-7]. Diabetes mellitus is the sixth leading cause of death globally [8]. Many of the drugs have been used in the management of this disease. These drugs have many side effects and a search for new class of compounds is essential to overcome diabetic problems [9]. Traditionally, a number of plants have been used in various herbal preparations in the management of diabetes and only few of them have been proven scientifically [10].

\section{Materials and Methods}

\section{Plant material}

Rumex vesicarius leaves were collected from Narsapur, Medak district and authenticated by D. Venkateshwara Rao, Deputy Director, A.P. Forest Academy, Dulapally, Hyderabad, Rangareddy District.

\section{Preparation of extracts}

The collected aerial parts of the plant were washed and dried under the shade. Around $500 \mathrm{~g}$ of the coarsely powdered aerial parts of the plant was packed in a soxhlet apparatus and extracted with ethanol.

\section{Animals}

Albino Wistar rats (weighing 150-200 g) of both sexes, were procured from NIN, Hyderabad, India and were housed in standard metal cages. They were provided with food, water \& ad libitium and allowed a one week acclimatization period prior to the study. The protocol was approved by Institutional animal ethical committee of VIPER, Narsapur Medak and the study was performed according to the CPCSEA guidelines (1358/ac/10/CPCSEA).

\section{In vitro antidiabetic activity}

In vitro $\boldsymbol{\alpha}$-glucosidase inhibition study: The tissue homogenate prepared from small intestine of rats was used as enzyme source. A small piece of small intestine was taken out in precooled phosphate buffer saline (PBS), thoroughly cleaned, dried on blotting paper, weighed and then homogenized in glass Teflon homogenizer. The homogenate was centrifuged at 5,000 rpm for $30 \mathrm{~min}$ and its supernatant was used as enzyme source. Final volume of supernatant was maintained to $20 \%(\mathrm{w} / \mathrm{v})$. The spectrophotmetric assay method was used with slight modification. Here, $40 \mu \mathrm{l}$ tissue homogenate was mixed with (1-9 $\mathrm{mg} / \mathrm{ml})$ test, standard, drug vector and incubated for 
$37^{\circ} \mathrm{C}$. Thereafter, $280 \mu \mathrm{l} \mathrm{maltose}(37 \mathrm{mM})$ was added and further incubated for $30 \mathrm{~min}$. Finally, the reaction was stopped by placing the tubes in boiling water for $10 \mathrm{~min}$. Glucose concentration was assessed using Accu-chek active.

Experimental Induction of Diabetes: Streptozotocin was freshly dissolved in $0.1 \mathrm{M}$ fresh cold citrate buffer $\mathrm{pH} 4.5$ and maintained on ice prior to use [11]. Diabetes was induced in overnight fasted rats by single intraperitoneal injection of streptozotocin $(60 \mathrm{mg} / \mathrm{kg})$, all animals were given free access to food and water. Blood glucose levels were measured 3 days after the streptozotocin injection and rats with fasting blood glucose levels greater than $200 \mathrm{mg} / \mathrm{dl}$ were considered to be diabetic used in the experiment.

\section{Experimental design}

5 groups of rats were used to study the effect of ethanolic leaf extract of Rumex vesicarius. Each group consists of 6 rats.

Group I: Disease control induced with $60 \mathrm{mg} / \mathrm{kg}$ of Streptozotocin (I.P).

Group II: Diabetic rats were treated with ethanolic leaf extracts of Rumex 100 mg/kg.

Group III: Diabetic rats were treated with ethanolic leaf extracts of Rumex 200 mg/kg.

Group IV: Diabetic rats were treated with ethanolic leaf extracts of Rumex $400 \mathrm{mg} / \mathrm{kg}$.

Group V: Diabetic rats were treated with Glibenclamide $10 \mathrm{mg} / \mathrm{kg}$ body weight.

Treatment of experimental animals with ethanolic extract was initiated 3 days post streptozotocin injection and was carried out daily by oral gavage for 7 days; food and water were made freely available. The blood glucose levels were determined by using Glucometer and the values of sample were compared with Glibenclamide. After the experimental regimen, the animals were sacrificed by cervical dislocation under mild ether anesthesia. The pancreas were exposed and perfused with cold saline and phosphate buffer of $\mathrm{pH} 7.4$ for histopathological examination.

\section{Statistical analysis}

The values were expressed as mean \pm SEM. The data was subjected to the analysis ofvariance (one way ANOVA) to determine the significance of changes followed by student's t-test [12-14].

\section{Results and Discussion}

\section{In vitro antidiabetic activity}

In vitro a-glycosidase inhibition activity: Rumex vesicarius showed a significant inhibitory action on a-glucosidase enzyme. The percentage inhibition at $1-9 \mathrm{mg} / \mathrm{ml}$ concentrations of Rumex vesicarius leaf extract showed a concentration dependent increase in the percentage inhibition. Rumex showed 59\% inhibition at $9 \mathrm{mg} / \mathrm{ml}$ and Acarbose showed $83 \%$ inhibition. The values are tabulated in Table 1. The inhibition of alpha glycosidase enzyme by the Rumex plant in the present study provides a strong biochemical basis for the management of diabetes.

\begin{tabular}{|l|l|l|}
\hline \multirow{2}{*}{ Plant Extract $(\mathbf{m g} / \mathbf{m l})$} & \multicolumn{2}{|l|}{$\%$ of inhibition } \\
\cline { 2 - 3 } & Rumex extract & Acarbose \\
\hline 1 & 18 & 19.01 \\
\hline 3 & 20 & 35.23 \\
\hline 5 & 21 & 54.22 \\
\hline 7 & 34 & 69.23 \\
\hline 9 & 59 & 83.06 \\
\hline
\end{tabular}

Table 1: In vitro a-glucosidase inhibition of Rumex vesicarius.

\section{In vivo antidiabetic activity}

A marked rise in fasting blood glucose levels were observed in diabetic group when compared with normal control rats. Ethanolic extract of Rumex vesicarius at $(100,200,400 \mathrm{mg} / \mathrm{kg})$ exhibited a dose dependent significant antidiabectic activity. All the values were shown in the Table 2. It was found that ethanolic extract at $400 \mathrm{mg} / \mathrm{kg}$ showed highly significant decrease in the blood glucose levels when compared to the control STZ induced diabetic animals which was compared with the standard drug Glibenclamide $(10 \mathrm{mg} / \mathrm{kg})$. The standard drug Glibenclamide stimulates insulin secretion from of islets of Langerhans.

\begin{tabular}{|c|c|c|c|c|c|c|}
\hline \multirow[b]{2}{*}{ Treatments } & \multirow[b]{2}{*}{ Dose $\mathrm{mg} / \mathrm{kg}$} & \multicolumn{5}{|c|}{ Blood glucose levels $(\mathrm{mg} / \mathrm{dL}$ ) in days } \\
\hline & & Day 0 & Day 1 & Day 3 & Day 5 & Day 7 \\
\hline Disease control & 60 & $205 \pm 1.2$ & $200 \pm 1.1$ & $201 \pm 1.4$ & $200 \pm 2.0$ & $200 \pm 2.1$ \\
\hline Rumex & 100 & $204 \pm 1.41$ & $184 \pm 2.17$ & $150 \pm 2.25$ & $131 \pm 4.12$ & $120 \pm 2.11$ \\
\hline Rumex & 200 & $205 \pm 2.1$ & $177 \pm 3.21$ & $144 \pm 2.14$ & $126 \pm 3.14$ & $114 \pm 1.25$ \\
\hline Rumex & 400 & $203 \pm 1.3$ & $145 \pm 2.22$ & $128 \pm 3.12$ & $117 \pm 2.71$ & $98 \pm 2.44$ \\
\hline Glibenclamide & 10 & $205 \pm 1.21$ & $132 \pm 2.88$ & $119 \pm 3.45$ & $101 \pm 4.11$ & $91 \pm 3.17$ \\
\hline
\end{tabular}

Table 2: Effect of leaf extracts of Rumex vesicarius on blood glucose level of streptozotocin -induced diabetic rats during prolonged treatment. 
Citation: Reddy NS, Ramanjaneyulu K, Sabbani V, Choday V (2017) In Vitro and in Vivo Antidiabetic Activity of Rumex Vesicarius Leaves Extract in Streptozotocin Induced Diabetic Albino Wister Rats. J Diabetes Metab 8: 745. doi:10.4172/2155-6156.1000745

Page 3 of 4

From this study it is suggested that the possible mechanisms by which the plant extract decrease the blood glucose levels may be potentiation of insulin effect either by increase in pancreatic secretion of insulin from beta cells of Islets of Langerhans. The pancreas of Albino rats shown in Figure 1 Shows normal architecture of the pancreatic lobe disrupted fibrous tissue between the lobes when treated with $400 \mathrm{mg} / \mathrm{kg}$ of rumex extract. The Figure 2 shows the necrosis of the islet cells. Pancreatic lobes are elongated and Figure 3 shows the degranulation and Vacuolization of beta cells and almost the complete recover of cells (Figure 4 ) when treated with the standard drug Glibenclamide.

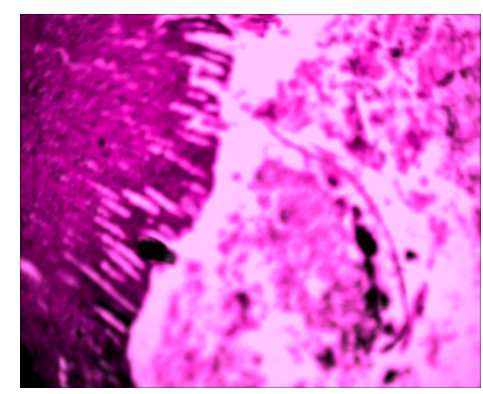

Figure 1: Treated with $400 \mathrm{mg} / \mathrm{kg}$ of ethanolic extract of Rumex vesicarius.

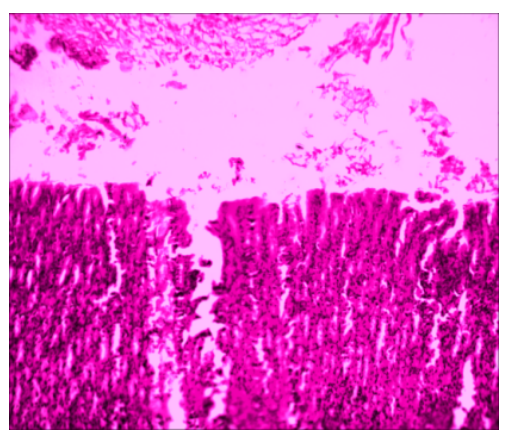

Figure 2: Treated with $200 \mathrm{mg} / \mathrm{kg}$ of ethanolic extract of Rumex vesicarius.

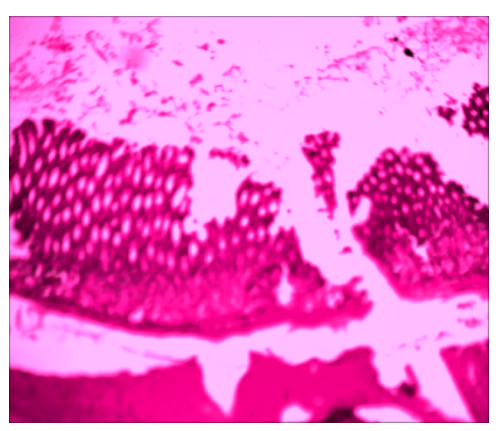

Figure 3: Treated with $100 \mathrm{mg} / \mathrm{kg}$ ethanolic extract of Rumex vesicarius.

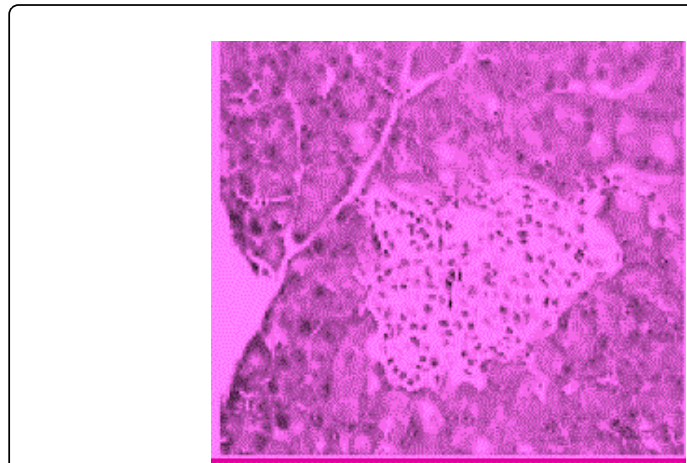

Figure 4: Treated with $10 \mathrm{mg} / \mathrm{kg}$ Glibenclamide.

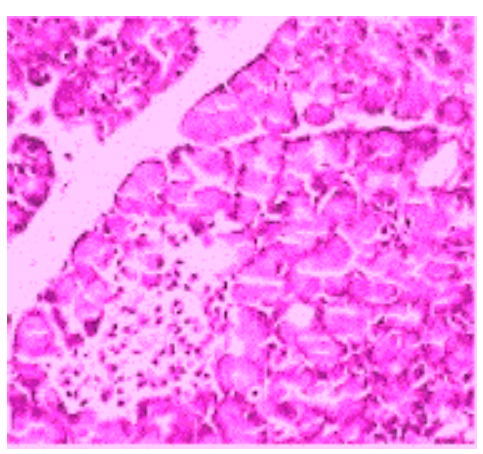

Figure 5: Streptozotocin Induced.

Histopathological Examination: The antidiabetic activity was confirmed through the histopathological pancreas of albino rats. For histopathological study the pancreas was removed after desection of rats and they were preserved in 10\% Formalin. They were given for hispothalogical studies.

\section{Acknowledgements}

We would like to thank our Chairman, A Ramesh, Principal and Sabbani S, VIPER, Narsapur, Medak for providing the facilities.

\section{References}

1. Madhavashetty K, Shivaji K, Tulasirao K (2008) Flowering plants of Chittoor district, Andhra Pradesh, India, 169: 201.

2. Batanouny KH (1999) Wild medicinal plants in Egypt. Academy of Scientific Research and Technology, Egypt and International Union for Conservation (IUCN), Switzerland, pp: 166- 167.

3. Al- Quran S (2009) Ethnopharmacological survey of wild medicinal plants in Showbak, Jordan. J Ethnopharmacol 123: 45-50.

4. Elegami AA1, Almagboul AZ, Omer ME, El Tohami MS (2001) Sudanese plants used in folkloric medicine: Screening for antibacterial activity. Fitoterapia 72: 810-817.

5. Rahman MA, Mossa JS, Al-Said MS, Al-Yahya MA (2004) Medicinal planT diversity in the flora of Saudi Arabia 1: a report on seven plant families. Fitoterapia 75: 149-161.

6. Abutbul S, Golan G, Barzani O, Ofir R, Zilberg D (2005) Screening of desert plants for use against bacterial pathogens in fish. Israeli J Aquaculture Bamidgeh 57: 71-80. 
Citation: Reddy NS, Ramanjaneyulu K, Sabbani V, Choday V (2017) In Vitro and in Vivo Antidiabetic Activity of Rumex Vesicarius Leaves Extract in Streptozotocin Induced Diabetic Albino Wister Rats. J Diabetes Metab 8: 745. doi:10.4172/2155-6156.1000745

Page 4 of 4

7. Prasuna CP, Chakradhar RP, Rao JL, Gopal NO (2009) EPR and IR spectral investigations on some leafy vegetables of Indian origin Spectrochim Acta A Mol Biomol Spectrosc 74: 140-147.

8. Nash D, Koenig J, Novielli K, Liberoni R, Reisman M (2001) The importance of the individualized pharmaceutical therapy in the treatment of diabetes mellitus. Dis Manag 4: 5-23.

9. Noor A, Gunasekaran S, Manickam AS, Vijayalakshmi MA (2008) Antidiabetic activity of Aloe vera and histology of organs in streptozotocininduced diabetic rats. Curr Sci 94: 1070-1076.

10. Jia Q, Liu X, Wu X, Wang R, Hu X, et al. (2009) Hypoglycemic activity of a polyphenolic oligomer-rich extract of Cinnamomum parthenoxylon bark in normal and streptozotocin-induced diabetic rats. Phytomedicine 16: 744-750.
11. S Vidhya, A Ramesh, S Shobharani (2014) Evaluation of anti-diabetic activity of ethanolic and methanolic extracts of leaves of curcuma inodora against streptozotocin induced diabetic rats. IOSR-JPBS 9: 45-49.

12. Snedecor GW, Cochran WG (1967) The comparison of two samples, in Statistical Methods, Iowa State University Press, Ames, Iowa, Pp: 91-119.

13. Woodson RF (1987) Statistical methods for the analysis of biomedical data series in probability and Mathematical statistics, wiley, New York, P: 315.

14. Zar JH (1974) Biostatistical Analysis, Prentice-Hall Inc, Englewood Chiffs NJ, P: 151. 